\title{
Quantitative Trait loci (QTL) Identification for Resistance to Mal de Rio Cuarto Virus (MRCV) in Maize Based on Segregate Population
}

\author{
Ezequiel A. Rossi*, María L. Borghi, Miguel A. Di Renzo and Natalia C. Bonamico
}

Facultad de Agronomía y Veterinaria, Universidad Nacional de Río Cuarto, Agencia no 3, 5800 Río Cuarto, Argentina

\begin{abstract}
Mal de Río Cuarto virus (MRCV) is one of the most devastating pathogens in maize (Zea mays L.) causing serious yield loss in susceptible cultivars in Argentina. An effective solution to control the virus is to use resistant genes to improve the behavior of susceptible genotypes. The goals of this work are to identify simple sequence repeats (SSR) linked to quantitative trait loci (QTL), for resistance to MRCV, and to validate QTL found in previous research with different genetic backgrounds. Two hundred and eight $\mathrm{F}_{2: 3}$ families derived from a cross between a susceptible inbred line, B73, and a resistant inbred line, LP116, were evaluated across three environments in the disease-endemic region. Disease incidence (INC), disease severity (SEV) and disease severity index (DSI) were employed to evaluate $\mathrm{F}_{2: 3}$ families. Based on this segregant population, ninety-eight simple sequence repeat (SSR) markers selected from 173 markers were used. The means of all measured traits followed near-normal distribution; therefore these traits may be considered as quantitatively inherited characters. For INC, SEV and DSI all estimates showed a moderate heritability ranging from 0,33 to 0,72. Some quantitative trait loci (QTL), each explaining around $10 \%$ of phenotypic variance were found on chromosome 1,6 , 8 and 10. The identification of QTL conferring resistance to MRCV may contribute to breeding programs seeking to protect the crop through improved genetic resistance.
\end{abstract}

Keywords: Mal de Río Cuarto virus (MRCV), Quantitative trait loci (QTL), Segregant population, Zea mays L.

\section{INTRODUCTION}

Maize (Zea mays L.) is the natural host of several viruses, but only some of these cause diseases that affect yield [1]. The Mal de Río Cuarto (MRC) disease is one of the most important viral diseases causing devastating yield loss in maize in Argentina [2]. This disease was detected for the first time in the late 60s in maize crops growing in Río Cuarto, southern Córdoba, Argentina. At present, it is distributed over almost all the corn growing areas in Argentina; however the area where the disease is endemic is the Río Cuarto region [3]. The main symptoms in maize are dwarfing, internode shortening, small ears with few or no kernels, and enations as a distinctive feature [3, 4].

The causal agent, Mal de Río Cuarto virus (MRCV) belongs to the Fijivirus genus, family Reoviridae [3]. A close relationship was reported between the Mal de Río Cuarto virus (MRCV) and the Maize rough dwarf virus (MRDV) that is found in Europe and the East Mediterranean [4]. MRCV is transmitted in a persistent, propagative manner by the planthopper Delphacodes kuscheli Fennah (Homoptera: Delphacidae) [5]. Wheat, oat and weeds are natural reservoirs of the virus. MRC disease epidemics occur when large populations of planthopper migrate from winter cereals to the emerging maize crop [6].

*Address correspondence to this author at the Facultad de Agronomía y Veterinaria, Universidad Nacional de Río Cuarto, Agencia n³, 5800 Río Cuarto, Argentina; E-mail: nbonamico@ayv.unrc.edu.ar
Conventional controlling approaches use chemical pesticides; however this could result in environmental pollution, and is not efficient enough. One of the effective ways to solve this problem is to breed resistant genotypes. The conventional breeding method is time-consuming, and the available resistant resources are limited. An alternative solution is to use resistant genes from resistant plants to improve susceptible cultivars [7].

The genetic diversity of maize has been helpful for the identification of resistant germplasm and the exploration of disease resistance genes, which are important in breeding programs [8]. The development of DNA-based markers provides a powerful alternative method for the dissection of complex traits [9]. DNA markers linked to MRCV resistance genes have been identified in several studies. In Argentina, previous research reported two [10] five [11] and four [12] quantitative trait loci (QTL) for resistance to MRC disease. In China [7] two QTL regions were identified associated with disease severity index (DSI) for Maize rough dwarf disease (MRDD).

In the present study, an early generation $\mathrm{F}_{2: 3}$ derived from the cross of B73 and LP116 was analyzed. The objectives of this study were to identify simple sequence repeats (SSR) linked to quantitative trait loci (QTL) contributing to resistance to MRCV, and to validate QTL found in previous research with different genetic backgrounds. 


\section{MATERIALS AND METHODS}

\section{Plant Materials}

A susceptible inbred line (B73, belonging to heterotic group Iowa Stiff Stalk Synthetic) and a resistant inbred line (LP116, developed in INTA Pergamino) were used as parents to obtain a segregant population. A total of $208 \mathrm{~F}_{2: 3}$ families obtained through single seed descent were employed in this study.

\section{Field Evaluation}

Trials were carried out in field experiments of the Universidad Nacional de Río Cuarto, at the Río Cuarto location $\left(33^{\circ} 06^{\prime} 16.08^{\prime \prime} \mathrm{S} ; 6^{\circ} 17^{\prime} 54.55^{\prime \prime} \mathrm{O}\right)$ during growing season 2010/11 and La Aguada location (32 58' 17.25" S; 64 38' 58.43" O) during growing seasons 2010/11 and 2011/12. Each year-location combination was used to define three environments. Río Cuarto 2010/11 (E1), La Aguada 2010/11 (E2) and La Aguada 2011/12 (E3). A randomized complete block design with two replications was used at each environment. Each trial was conducted under natural infection establishing the plots where the preceding crop was winter oat, which constitutes a reservoir for both vector and virus.

\section{Phenotypic Data}

Symptoms were measured visually on each plant using a scale [6]. This rating allowed quantification of the resistance to MRCV by means of three traits. Such traits are disease incidence (INC), disease severity (SEV) [12], and disease severity index (DSI) $[7,13,14]$.

\section{Genotypic Data}

Plant material from the parents and individual $F_{2}$ plants was used for DNA extraction. Total genomic DNA was isolated using a CTAB method [15]. DNA quantity and quality were measured with a Photometer (NanoDrop ${ }^{\circledR}$ ND-1000 Technologies Inc., Nilmington, DE, USA). SSR markers and primer sequences were obtained from the Maize Database website (http://www.maizegdb.org), and were chosen according to their bin location by providing a good coverage of the genome. One hundred and seventy-three SSRs were used for screen polymorphism between the two parents, and then ninety-eight markers that had polymorphism were used to analyze the $\mathrm{F}_{2: 3}$ families.

\section{Data analysis}

The INC, SEV and DSI traits at individual environments and across environments were analyzed by ANOVA using the MIXED procedure of SAS software [16]. The $\mathrm{F}_{2: 3}$ families (genotypes) and environments were considered random effects, being defined as follows:

$Y=\mu+E+B(E)+G+G \times E+e$

where $Y$ is the response variable, $\mu$ is the overall mean, $E$ is the environment effect, $B(E)$ is the block within environment effect, $G$ is the genotype effect, $G \times E$ is the genotype by environment interaction effect and $e$ is an error term.

Estimates of variance components and broad-sense heritabilities of traits were calculated on an $\mathrm{F}_{2: 3}$ family mean basis for each environment and across environments. Estimates of variance components, including genotypic variance $\left(\sigma_{\mathrm{g}}^{2}\right)$, genotype $\times$ environment interaction $\left(\sigma_{\mathrm{ge}}^{2}\right)$ and residual $\left(\sigma_{\mathrm{e}}^{2}\right)$, were calculated by equating the mean square to their expected values. A broad-sense heritability estimate based on variance component was calculated [17] for each environment:

$H=\sigma_{g}^{2} /\left(\sigma_{g}^{2}+\sigma_{e}^{2} / r\right)$

and across environments by:

$H=\sigma_{\mathrm{g}}^{2} /\left(\sigma_{\mathrm{g}}^{2}+\sigma_{\mathrm{ge}}^{2} / \mathrm{e}+\sigma_{\mathrm{e}}^{2} / \mathrm{re}\right)$

where $e$ is the number of environments, and $r$ is the number of replications in each environment.

Two-sided 90\% confidence intervals were also computed to determine the precision of heritability value estimated. The $90 \%$ confidence limits for $h^{2}$ were defined according to [18].

\section{QTL Analysis}

A linkage map was constructed using MapMaker/EXP 3.0 [19]. Simple interval mapping (SIM) [20] and composite interval mapping (CIM) [21] were employed using PlabQTL software [22]. Phenotypic variation explained for putative QTL was estimated through a multiple regression model.

\section{RESULTS}

The incidence (INC), severity (SEV) and disease severity index (DSI) in $\mathrm{F}_{2: 3}$ families ranged between low and medium values in the three environments, indicating high infection levels. However, the $\mathrm{F}_{2: 3}$ families were not consistent across environments because the means were not similar among environments. The LP116 line, the resistant parent, exhibited less INC, SEV and DSI than B73 line, the susceptible parent. This difference was significant $(\mathrm{P}<0.05)$ at each environment and across environments. The INC, SEV and DSI means of $\mathrm{F}_{2: 3}$ families also were significantly different $(\mathrm{P}<0.05)$ from parents at each environment and across environments (Table 1).

The mean distribution for INC, SEV and DSI of $\mathrm{F}_{2: 3}$ families is shown in Fig. 1 (a, b and $\mathbf{c}$ ), respectively. These distributions followed near-normal distribution; therefore the traits were quantitatively inherited characters. The parental lines were situated close to the boundaries of the distributions for incidence (Fig. 1a) and the disease severity index (Fig. 1c), so that transgressive segregants could not be observed for these two traits. For SEV trait, about ten $\mathrm{F}_{2: 3}$ families presented a higher SEV value than the susceptible parent. This indicates a small transgressive segregation in this trait (Fig. 1b).

All traits evaluated for disease assessment showed moderate heritability estimates, ranging from 0.33 to 0.72 , both 
Table 1. Means ( \pm S.E.) of disease assessment traits of parents LP116 and B73 and of a derived mapping population of $208 \mathrm{~F}_{2: 3}$ families; measured at each individual environment and across environments.

\begin{tabular}{|c|c|c|c|c|c|c|c|c|c|}
\hline \multirow{2}{*}{ Trait* } & \multirow{2}{*}{ Genotype } & \multicolumn{6}{|c|}{ Environment } & \multirow{2}{*}{\multicolumn{2}{|c|}{ Across Environments }} \\
\hline & & E1 & & E2 & & $\mathbf{E 3}$ & & & \\
\hline \multirow[t]{4}{*}{ INC } & LP116 & $0,00 \pm 0,00$ & $\mathrm{a}$ & $0,00 \pm 0,00$ & $\mathrm{a}$ & $0,00 \pm 0,00$ & a & $0,00 \pm 0,00$ & $\mathrm{a}$ \\
\hline & B73 & $0,84 \pm 0,06$ & $\mathrm{c}$ & $1,00 \pm 0,00$ & $\mathrm{c}$ & $1,00 \pm 0,00$ & $\mathrm{c}$ & $0,95 \pm 0,04$ & $\mathrm{c}$ \\
\hline & $\mathrm{F}_{2: 3}$ & $0,47 \pm 0,02$ & $\mathrm{~b}$ & $0,61 \pm 0,02$ & $\mathrm{~b}$ & $0,58 \pm 0,02$ & $\mathrm{~b}$ & $0,55 \pm 0,01$ & $\mathrm{~b}$ \\
\hline & LSD & 0,25 & & 0,28 & & 0,33 & & 0,17 & \\
\hline \multirow[t]{4}{*}{ SEV } & LP116 & - & & - & & - & & - & \\
\hline & B73 & $1,99 \pm 0,13$ & $\mathrm{~b}$ & $2,81 \pm 0,01$ & $\mathrm{~b}$ & $2,61 \pm 0,06$ & $\mathrm{a}$ & $2,47 \pm 0,16$ & $\mathrm{~b}$ \\
\hline & $\mathrm{F}_{2: 3}$ & $1,56 \pm 0,03$ & $\mathrm{a}$ & $2,09 \pm 0,04$ & $\mathrm{a}$ & $2,59 \pm 0,04$ & $\mathrm{a}$ & $2,06 \pm 0,02$ & $\mathrm{a}$ \\
\hline & LSD & 0,34 & & 0,39 & & 0,33 & & 0,24 & \\
\hline \multirow[t]{4}{*}{ DSI } & LP116 & $0,00 \pm 0,00$ & a & $0,00 \pm 0,00$ & $\mathrm{a}$ & $0,00 \pm 0,00$ & $\mathrm{a}$ & $0,00 \pm 0,00$ & a \\
\hline & B73 & $55,67 \pm 7,67$ & $\mathrm{c}$ & $93,67 \pm 0,34$ & $\mathrm{c}$ & $87,00 \pm 2,00$ & $\mathrm{c}$ & $78,78 \pm 7,69$ & $\mathrm{c}$ \\
\hline & $\mathrm{F}_{2: 3}$ & $24,89 \pm 1,96$ & $\mathrm{~b}$ & $43,08 \pm 1,50$ & $\mathrm{~b}$ & $49,35 \pm 1,89$ & $\mathrm{~b}$ & $39,11 \pm 0,93$ & $\mathrm{~b}$ \\
\hline & LSD & 17,36 & & 24,45 & & 31,06 & & 15,14 & \\
\hline
\end{tabular}

* Disease assessment. INC, disease incidence; SEV, disease severity; DSI: Disease severity index. \pm Standard error

LSD: Least significant difference for comparing the means of individual $\mathrm{F}_{2: 3}$ families at $P=0.05$.

Column means followed by the same letter were not significantly different at the 0.05 probability level, according to a LSD test.

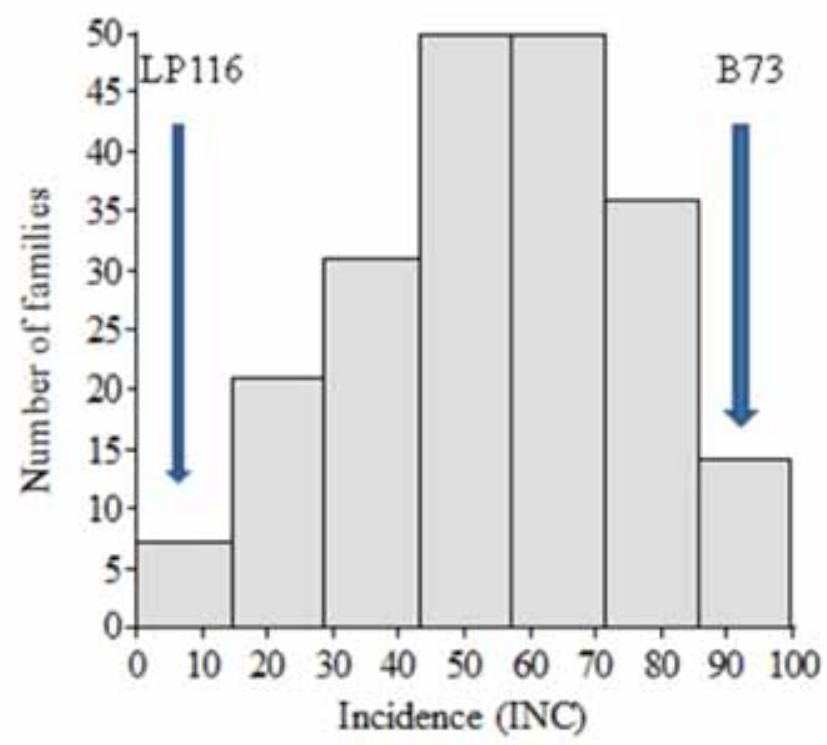

(a)

Fig. (1). Contd... 


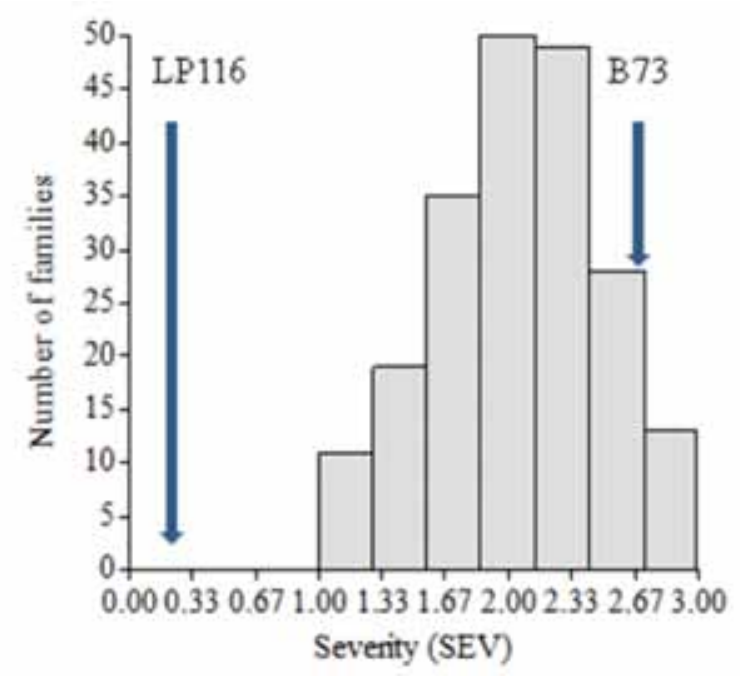

(b)

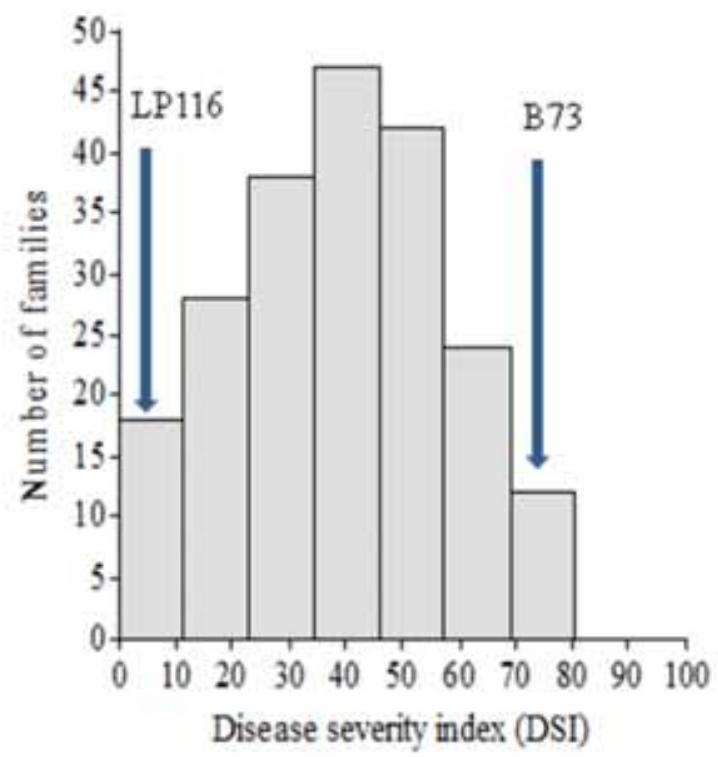

(c)

Fig. (1). Distribution of $\mathrm{F}_{2: 3}$ families for incidence (INC) (a), severity (SEV) (b) and disease severity index (DSI) (c) in three environments. Parental mean values are indicated.

Table 2. Estimates of variance components, broad-sense heritability, and confidence intervals (CI) for incidence (INC), severity (SEV) and disease severity index (DSI) to MRC in $208 \mathrm{~F}_{2: 3}$ families measured at each individual environment and across environments.

\begin{tabular}{|c|c|c|c|c|}
\hline \multirow{3}{*}{$\begin{array}{c}\text { Parameters } \\
\text { Variance Components }\end{array}$} & \multicolumn{3}{|c|}{ Environment } & \multirow{3}{*}{ Across Environments } \\
\hline & \multirow{2}{*}{ E1 } & \multirow{2}{*}{ E2 } & \multirow{2}{*}{$\mathbf{E 3}$} & \\
\hline & & & & \\
\hline \multicolumn{5}{|c|}{ Trait: INC } \\
\hline$\sigma^{2} g$ & $0,048 \pm 0,008$ & $0,058 \pm 0,009$ & $0,097 \pm 0,014$ & $0,022 \pm 0,005$ \\
\hline$\sigma^{2} e$ & $0,057 \pm 0,006$ & $0,064 \pm 0,006$ & $0,077 \pm 0,008$ & $0,066 \pm 0,004$ \\
\hline$\sigma^{2} g e$ & - & - & & $0,045 \pm 0,006$ \\
\hline
\end{tabular}


Table 2. contd...

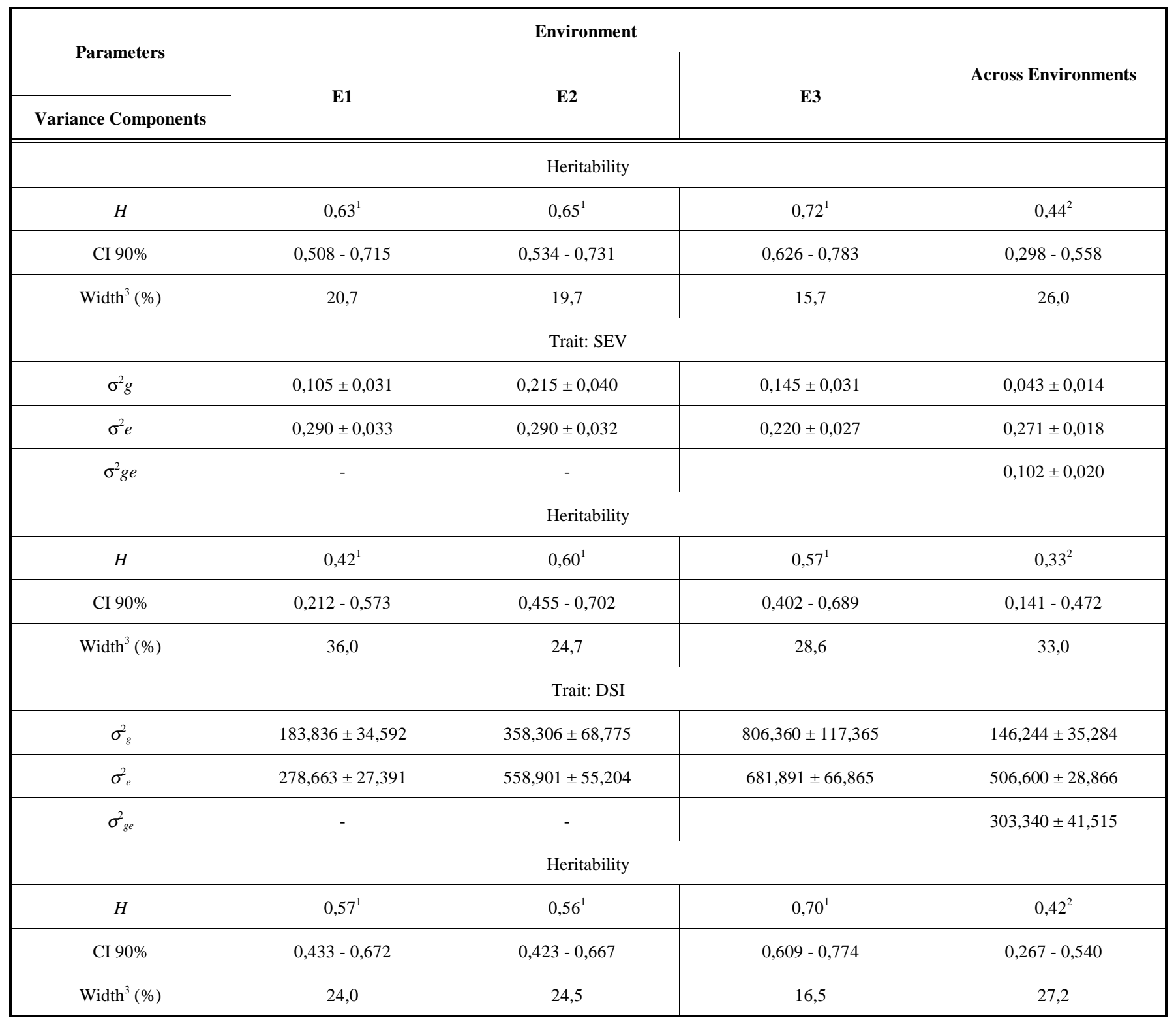

\pm Standard error.

${ }^{1} H=\sigma_{g}^{2} /\left(\sigma_{g}^{2}+\sigma_{e}^{2} / \mathrm{r}\right) ; \mathrm{r}=$ replication number

${ }^{2} H=\sigma_{g}^{2} /\left(\sigma_{g}^{2}+\sigma_{g e}^{2} / \mathrm{e}+\sigma_{e}^{2} / \mathrm{re}\right) ; \mathrm{r}=$ replication number y e= environment number.

${ }^{3}$ Expressed as the ratio $(\%)$ of the confidence interval width relative to the heritability point estimate.

Table 3. Parameter associated with QTL for incidence (INC), severity (SEV) and disease severity index (DSI) to MRC, in a mapping population of $208 \mathrm{~F}_{2: 3}$ families derived from the cross B73 x LP116 across environments.

\begin{tabular}{|c|c|c|c|c|c|}
\hline Trait & QTL Position $^{1}$ & Environment $^{2}$ & LOD Score $^{3}$ & Additive Effect $^{\mathbf{2}}$ & $-0,29$ \\
\hline \hline INC & $1.03($ bnl1866) & E2 & $6,78 \mathrm{a}$ & $-0,07$ & 14,2 \\
\hline & $1.03($ umc1021) & E1 & $6,02 \mathrm{ab}$ & $-0,26$ & 12,6 \\
\hline & $1.07(\mathrm{bnlg} 1025)$ & E2 & E1 & $3,13 \mathrm{a}$ & 0,09 \\
\hline
\end{tabular}


Table 3. contd...

\begin{tabular}{|c|c|c|c|c|c|}
\hline Trait & QTL Position $^{1}$ & Environment $^{2}$ & LOD Score ${ }^{3}$ & Additive Effect & $R^{2}$ \\
\hline & 10.04 (bnlg 1074) & E2 & $9,08 \mathrm{a}$ & $-0,27$ & 18,5 \\
\hline \multirow{3}{*}{ SEV } & 1.03 (umc 1021) & E2 & 3,39ab & $-0,36$ & 8,0 \\
\hline & 6.05 (bnlg 1443) & E1 & $3,44 \mathrm{~b}$ & $-0,03$ & 8,6 \\
\hline & 8.08 (phi 080) & E1 & $2,72 \mathrm{a}$ & 0,27 & 6,7 \\
\hline \multirow[t]{3}{*}{ DSI } & 1.03 (bnlg 1866) & E2 & $5,10 \mathrm{~b}$ & $-0,49$ & 10,8 \\
\hline & 1.03 (umc 1021) & E1 & $3,96 \mathrm{ab}$ & $-0,12$ & 8,5 \\
\hline & 10.03 (bnlg 640) & $\mathrm{E} 2$ & $2,62 b$ & $-0,28$ & 5,7 \\
\hline
\end{tabular}

${ }^{1}$ Chromosomal location: bin and nearest marker.

${ }^{2}$ Combinations locality-year, E1: Río Cuarto 2010-11, E2: La Aguada 2010-11; E3: La Aguada 2011-12

${ }^{3}$ Likelihood of odds (LOD) score. a and b QTL detected using CIM and SIM method, respectively.

$R^{2}$ : Phenotypic variation explained by the QTL.

in individual environments and across environments (Table 2). The differences in the INC, SEV and DSI of $\mathrm{F}_{2: 3}$ families across all environments were due to significant genotypeenvironment interaction and the moderate heritability value estimated. For disease severity index and incidence the heritability ranged from 0.42 to 0.70 . While for severity trait the higher heritability estimates were presented in E2 (Table 2).

Ninety-eight SSR markers that were polymorphic between parents were used to analyze the mapping population. The chromosomal locations of marker intervals, effect of each QTL and determination coefficients on incidence (INC), severity (SEV) and disease severity index (DSI), for each environment are presented in Table 3. Four QTL regions were identified for INC trait. Three regions were associated with alleles for MRC resistance from LP116, while the QTL detected in bin 8.08 was associated with alleles for MRC resistance, which came from susceptible parent B73. These regions explained between $7 \%$ and $19 \%$ of the phenotypic variation. Five QTL regions were found for SEV trait in bins 1.02, 1.03, 4.05, 6.05 and 8.08. Four QTL associated to DSI with a LOD score $>2.5$ were found in bins $1.03,1.07$, 8.08 y 10.03 . These QTL showed additive negative effects, which were associated with alleles for MRC resistance came from resistant parent LP116. Phenotypic variation explained by these QTL ranged between 5 and $11 \%$.

QTL analysis across environments presented regions associated with the three traits evaluated. The QTL were found in chromosomes 1 (bins $1.03 ; 1.07$ ) and 10 (bins 10.04; 10.06). Four QTL were identified with CIM method employing eight, five and seven cofactors for DSI, INC and SEV traits, respectively. Three of these regions were also identified using SIM method. All QTL regions showed additive negative effects, therefore they were associated with alleles for MRC resistance from LP116. Phenotypic variation explained for each QTL ranged between 5 and $11 \%$ (Table 4).

\section{DISCUSSION}

MRC, like all viral diseases, requires interactions among a competent vector, the virulent pathogen, a susceptible host and a suitable environment [2]. Transmission under controlled conditions in the laboratory offers the advantage of consistently, achieving high and uniform rates of pathogen transmission that simplifies phenotypic analysis of populations segregant for resistance [23], but it is not suitable in MRC disease because it is transmitted in a persistent propagative manner. However, in the present study natural infection was used and a good disease pressure was obtained for the evaluation from $\mathrm{F}_{2: 3}$ families.

Heritability estimates were performed in broad-sense because they are based on differences among $\mathrm{F}_{2: 3}$ families that reflect both additive and non additive genetic differences. For DSI trait, the estimate heritability was coincident with results obtained in a $F_{2: 3}$ segregant population with a different genetic background to the present study [13]. A higher heritability value for DSI of Maize rough dwarf disease (MRDD) was obtained in China [7]. While in a RIL population smaller heritabilities for INC, SEV and DSI traits were obtained [12]. In our assay like in previous studies $[12,13]$ a high genotype-environment interaction was observed. This resulted in an inconsistent response of $\mathrm{F}_{2: 3}$ families across environments.

Plants have developed a wide range of methodologies to cope with the invading pathogens causing diseases [8]. Most complex traits, as MRC in maize and other viral diseases; are controlled by polygenes or QTL with small individual effects $[12,24,25]$. Therefore the combination of several quantita- 
Table 4. Parameter associated with QTL for incidence (INC), severity (SEV) and disease severity index (DSI) to MRC, in a mapping population of $208 F_{2: 3}$ families derived from the cross B73 x LP116 across environments.

\begin{tabular}{|c|c|c|c|c|}
\hline Trait & QTL Position $^{1}$ & LOD Score $^{2}$ & Additive Effect & $R^{2}$ \\
\hline \multirow[t]{4}{*}{ INC } & 1.07 (bnlg1025) & $3,68 \mathrm{ab}$ & $-0,49$ & 7,9 \\
\hline & 10.04 (bnlg1074) & $2,59 \mathrm{ab}$ & $-0,38$ & 5,6 \\
\hline & 10.06 (umc1045) & $4,56 \mathrm{ab}$ & $-0,53$ & 9,7 \\
\hline & 1.03 (umc1021) & $5,04 \mathrm{a}$ & $-0,28$ & 10,8 \\
\hline SEV & $10.04($ bnlg1074) & $4,04 \mathrm{~b}$ & $-0,35$ & 8,8 \\
\hline \multirow[t]{3}{*}{ DSI } & 1.03 (bnlg1866) & $3,90 \mathrm{ab}$ & $-0,57$ & 8,3 \\
\hline & 1.07 (bnlg 1025) & $3,59 \mathrm{ab}$ & $-0,15$ & 7,7 \\
\hline & $10.04($ bnlg1074) & $3,10 \mathrm{ab}$ & $-0,17$ & 6,7 \\
\hline
\end{tabular}

${ }^{1}$ Chromosomal location: bin and nearest marker.

${ }^{2}$ Likelihood of odds (LOD) score. a and b QTL detected using CIM and SIM method, respectively.

$R^{2}$ : Phenotypic variation explained by the QTL.

tive resistance genes is necessary to achieve a high level of resistance in a genotype [26]. Improvement for MRC resistance should be made by combining resistance genes from different sources and by simultaneous selection for resistance and desirable agronomic traits across several environments [27].

In previous studies, two QTL for MRC resistance were detected on chromosomes 1 and 8 in an early generation derived from the cross between Mo17 and BLS14 [10], while Kreff et al. [11] identified five regions associated to MRC symptoms in one early generation derived from different parents. In the present study we have detected three QTL on bins 1.03, 1.07 and 10.04, which were also reported using different genetic backgrounds $[10,11]$. By comparing the present results against those previously reported in a late selfing generation [12], it was possible to observe that a QTL associated with INC and SEV was detected in the same genomic regions (bin 8.08), in both early and late generations. On bin 10.03, where a QTL-MRC linked to marker bnlg640 for DSI was mapped, a QTL conferring resistance to maize chlorotic dwarf virus was previously identified [24]. The agreement of findings between these mapping populations may be considered an indication of the existence of these QTL and may encourage the undertaking of further research on these regions. In the present study QTL were found in different genome regions for INC and SEV. Dintinger et al. [28] suggest that this is due to the fact that they involve different resistance mechanisms in the resistance to virus.

This research and previous studies with different mapping populations, different genetic backgrounds and environments identified QTL for resistance to MRC in chromosomes $1,3,4,6,8$ and 10 [10-12].

In summary, the resistance to MRCV observed in $\mathrm{F}_{2: 3}$ families were controlled by few genes with small individual effects. In addition, several QTL conferring resistance to MRC disease were mapped on chromosomes 1, 6, 8 and 10 at the same regions where other virus resistance has been reported. The identification of QTL conferring resistance to MRC disease suggests that maize germplasm may contribute to breeding programs seeking to protect the crop through improved genetic resistance. For instance, introgression QTL regions on chromosomes $1,6,8$, and/or 10 into elite genotypes could improve resistance to MRC and other viral diseases which cause significant economic losses. The most effective and sustainable means to the prevention of virus diseases is through the deployment of genetic resistance [26]. This approach, in combination with an integrated management, will help to set criteria for sustainable control of $\mathrm{MRC}$ in maize.

\section{CONFLICT OF INTEREST}

The authors declare that this article content has no conflict of interest.

\section{ACKNOWLEDGEMENTS}

The authors would like to thank Daniel Presello for providing the seeds of resistant parental line to MRC.

The authors would like to acknowledge the help of Ileana Martinez for improvements in the language editing.

This work was supported by grants from Universidad Nacional de Río Cuarto and Agencia Nacional de Promoción Científica y Tecnológica, PICT-1878/12-BID.

\section{REFERENCES}

[1] Zambrano JL, Jones MW, Brenner E, Francis DM, Tomas A, Redinbaugh MG. Genetic analysis of resistance to six virus diseases in a multiple virus-resistant maize inbred line. Theor Appl Genet 2014; 127: 867-80.

[2] Redinbaugh MG, Pratt RC. Virus resistance. Handbook of Maize: Its Biology. In: Bennetzen JL, Hake SC, Eds. New York: Springer Verlag 2009; pp. 251-70.

[3] Arneodo JD, Lorenzo E, Laguna IG, Abdala G, Truol GA. Cytopathological characterization of Mal de Río Cuarto virus in corn, wheat and barley. Fitopatol Bras 2002; 27: 298-302.

[4] Nome SF, Lenardón SL, Raju BC, Laguna IG, Lowe SK, Docampo D. Association of reovirus-like particles with Enfermedad de Río 
IV of maize in Argentina. Phytopathologische Zeitschrift 1981; 101: 7-15.

[5] Ornaghi JA, Boito G, Sanchez G, March G, Beviacqua JE. Studies on the populations of Delphacodes kuscheli Fennah in different years and agricultural areas. J Genet Breed 1993; 47: 277-82.

[6] Ornaghi JA, March GJ, Boito, GT, et al. Infectivity in natural populations of Delphacodes kuscheli vector of "Mal de Río Cuarto" virus. Maydica 1999; 44: 219-23.

[7] Luan J, Wang F, Li Y, Zhang B, Zhang J. Mapping quantitative trait loci conferring resistance to rice blackstreaked virus in maize (Zea mays L.). Theor Appl Genet 2012; 125: 781-91.

[8] Ali F, Yan J. Disease resistance in maize and the role of molecular breeding in defending against global threat. J Integr Plant Biol 2012; 54: 134-51.

[9] Ragimekula N, Varadarajula NN, Mallapuram SP, Gangimeni G, Reddy RK, Kondreddy HR. Marker assisted selection in disease resistance breeding. J Plant Breed Genet 2013; 01: 90-109.

[10] Di Renzo MA, Bonamico NC, Diaz DG, et al. Microsatellite markers linked to QTL for resistance to Mal de Río Cuarto disease in Zea mays L. J Agric Sci 2004; 142: 289-95.

[11] Kreff ED, Pacheco MG, Díaz DG, et al. Resistance to Mal de Río Cuarto virus in maize: A QTL mapping analysis. J Basic Appl Genet 2006; 17: 41-50.

[12] Bonamico N, Di Renzo M, Ibañez M, et al. QTL analysis of resistance to Mal de Río Cuarto disease in maize using recombinant inbred lines. J Agric Sci 2012; 150: 619-29.

[13] Di Renzo MA, Bonamico NC, Diaz DD, Salerno JC, Ibañez MM, Gesumaria JJ. Inheritance of resistance to Mal de Río Cuarto (MRC) disease in Zea mays (L.). J Agric Sci 2002; 139: 47-53.

[14] Grau CR, Radke VL. Resistance of soybean cultivars to Sclerotinia sclerotiorum. Plant Dis 1982; 66: 506-8.

[15] Saghai-Maroof MA, Soliman KM, Jorgensen RA, Allard RW. Ribosomal DNA spacer-length polymorphisms in barley: mendelian inheritance, chromosomal location, and population dynamics. Proc Nat Acad Sci USA 1984; 81: 8014-8.
[16] SAS Institute. SAS/STAT release 9.1. Cary, NC: SAS Institute 2002.

[17] Hallauer AR, Miranda JB. Quantitative genetics in maize breeding. Ames, IA: Iowa State University Press 1981.

[18] Knapp SJ, Stroup WW, Ross WM. Exact confidence intervals for heritability on a progeny mean basis. Crop Sci 1985; 25: 192-4.

[19] Lander ES, Green P, Abrahamson J, et al. Mapmaker: an interactive computer package for constructing primary genetic linkage maps of experimental and natural populations. Genomics 1987; 1: 174-81.

[20] Lander ES, Botstein D. Mapping mendelian factors underlying quantitative traits using RFLP linkage maps. Genetics 1989; 121: 185-99.

[21] Jiang C, Zeng ZB. Multiple trait analysis of genetic mapping for quantitative trait loci. Genetics 1995; 140: 1111-27.

[22] Utz HF, Melchinger AE. PLABQTL. A program for composite interval mapping of QTL. J Agric Genomics 1996. Available from: http://wheat.pw.usda.gov/jag/papers96/paper196/utz.html

[23] Jones MW, Redinbaugh MG, Anderson RJ, Louie R. Identification of quantitative trait loci controlling resistance to maize chlorotic dwarf virus. Theor Appl Genet 2004; 110: 48-57.

[24] Hao D, Cheng Y, Chen G, et al. Identification of significant single nucleotide polymorphisms for resistance to maize rough dwarf disease in elite maize (Zea mays L.) inbred lines. Euphytica 2014; 203: 109-20.

[25] Würschum T. Mapping QTL for agronomic traits in breeding populations. Theor Appl Genet 2012; 125: 201-10.

[26] Maule AJ, Caranta C, Boulton MI. Sources of natural resistance to plant viruses: status and prospects. Mol Plant Pathol 2007; 8: 22331.

[27] Jiang GL. Molecular markers and marker-assisted breeding in plants. 2013. Available from: http://dx.doi.org/10.5772/52583

[28] Dintinger J, Verger D, Caiveau S, et al. Genetic mapping of maize stripe disease resistance from the Mascarene source. Theor Appl Genet 2005; 111: 347-59.

(C) Rossi et al.; Licensee Bentham Open.

This is an open access article licensed under the terms of the Creative Commons Attribution Non-Commercial License (http://creativecommons.org/licenses/by-nc/3.0/) which permits unrestricted, non-commercial use, distribution and reproduction in any medium, provided the work is properly cited. 